\title{
Potential of Organic Wastes as Liming Materials in Low Input Rainfed Agricultural System
}

\author{
T. P. Swarnam ${ }^{1} \&$ A. Velmurugan ${ }^{1}$ \\ ${ }^{1}$ Division of Natural Resource Management, Central Island Agricultural Research Institute, Port Blair, India \\ Correspondence: A. Velmurugan, Division of Natural Resource Management, Central Island Agricultural \\ Research Institute, Port Blair-744 101, India. Tel: 91-31912-251-319. E-mail: jcyang@yzu.edu.cn
}

Received: March 25, 2014 Accepted: May 4, 2014 Online Published: July 15, 2014

doi:10.5539/jas.v6n8p1 URL: http://dx.doi.org/10.5539/jas.v6n8p1

\begin{abstract}
A field experiment was conducted on an acid soil in a humid tropical Island of Andaman, India to explore the feasibility of using locally available organic wastes as liming materials after suitable composting. The organics such as coconut husk compost, poultry manure, vermicompost and gliricidia were incorporated at the rate of 20 $\mathrm{Mg} \mathrm{ha}^{-1}$ and the amendment effect was compared with lime applied at the rate of $4 \mathrm{Mg} \mathrm{ha}^{-1}$. Soil application of composted organic wastes significantly increased the soil $\mathrm{pH}$. The exchangeable $\mathrm{Al}^{3+}$ showed significant reduction in organic amended soils and completely disappeared in poultry manure and lime treated soils. Significant differences were observed in root volume by application of $\mathrm{N}$ rich organic materials compared to control $\left(11.7 \mathrm{~mm}^{3}\right)$ and lime $\left(23.3 \mathrm{~mm}^{3}\right)$ application which helped in increasing volume of soil foraged by maize roots. Poultry manure $\left(3.79 \mathrm{t} \mathrm{ha}^{-1}\right)$ and vermicompost $\left(3.73 \mathrm{t} \mathrm{ha}^{-1}\right)$ application recorded on par maize grain yield but significantly higher than the control $\left(1.93 \mathrm{t} \mathrm{ha}^{-1}\right)$. The results showed the potential of poultry manure and coconut husk composted with either poultry manure or gliricidia as alternate liming material for low input agricultural system prevailing in humid tropical Islands.
\end{abstract}

Keywords: soil acidity, liming, organic amendments, relative liming efficiency

\section{Introduction}

Low fertility is the major factor limiting crop production in many humid tropical countries where precipitation exceeds evaporation. High weathering and leaching of metal cations from soils result in soil acidity and low fertility in this region. Soil acidity combined with high concentrations of $\mathrm{Al}^{3+}$, are the major limiting factor for crop growth and biological activity in such soils. In acid soils solubility, sorption or precipitation of nutrients are affected by low $\mathrm{pH}$, presence of oxides and hydroxides of iron $(\mathrm{Fe})$ and aluminum $(\mathrm{Al})$ which affects the availability of plant nutrients especially phosphorus (P). The low soil pH also affects microbial activity and decomposition of organic matter in soil resulting in inefficient organic waste recycling and nutrient use (Sanchez et al., 1997; Kochian et al., 2004,).

There are different materials of organic and inorganic origin which reduces soil acidity and improves soil $\mathrm{pH}$. Limestone is commonly applied as amendment to raise the $\mathrm{pH}$ to near neutrality for improving productivity of acid soils. This improves the availability of macro nutrients such as $\mathrm{N}, \mathrm{P}, \mathrm{Ca}$ and $\mathrm{Mg}$ and reduces the solubility of $\mathrm{Al}^{3+}$ and $\mathrm{Mn}^{2+}$ which are toxic to crop plants (O' Hallorans et al., 1997). Nonetheless, organic materials such as wood ash (Materechera, 2012), poultry manure (Chandrashekara et al., 2000; Haynes \& Mokolobate, 2001; Amusan et al., 2011), green and animal manures (Nziguheba et al., 2000) were also reported to increase the $\mathrm{pH}$ of acid soils and improve soil fertility by supplying essential plant nutrients. The increase in maize grain yield by application of organic manures and crop residues in acid soils was also reported (Nziguheba et al., 2000; The et al., 2006).

Soil acidity poses a major constraint for crop production in the tropical islands of Andaman and Nicobar Islands, where majority of the agricultural area is affected by acidity of varying degrees. Similar to this, soil acidity caused by weathering and leaching of basic cations is also observed in other tropical countries/islands experiencing hot and humid tropical climate. Application of lime is a costly solution due to transportation cost and local non availability. Though the cattle manure and poultry manure are available in sizable quantities with small and marginal farmers of the Island, they are not properly used for ameliorating soil acidity. Growing gliricidia (Gliricidia sepium (Jacq.) Kunth ex Walp.) on farm boundaries is a common practice in these Islands 
which can be an organic nutrient source. Besides, coconut husk is available in plenty as more than $40 \%$ of agricultural area of these Islands is under coconut plantations. Approximately $8100 \mathrm{~kg} \mathrm{ha}^{-1} \mathrm{year}^{-1}, 3500 \mathrm{~kg} \mathrm{ha}^{-1}$ year ${ }^{-1}, 1250 \mathrm{~kg} \mathrm{ha}^{-1}$ year $^{-1}$ of organic wastes are generated in Andaman and Nicobar Islands from coconut, paddy and gliricidia, respectively, besides $1500 \mathrm{~kg}$ cow dung $\operatorname{cow}^{-1}$ year $^{-1}$ (Din et al., 2008).

These organic wastes can be a potential source of amendment for the acid soils of these Islands if properly recycled and used. Therefore, composting of crop residues and coconut husk was done using locally collected earthworms to improve their applicability as amendments for acid soil. In the present study the effect of different organic amendments on soil physico-chemical properties as well as growth and yield of maize was studied by direct application and in combination with poultry manure under field conditions.

\section{Materials and Methods}

\subsection{The Study Area}

The study was conducted in the tropical islands of Andaman located at about $1200 \mathrm{~km}$ from the Indian mainland in the Bay of Bengal, between the geographical location of $10^{\circ}$ to $14^{\circ} \mathrm{N}$ latitude and $92^{\circ}$ to $94^{\circ} \mathrm{E}$ longitudes. The prevailing climate is hot humid tropical with the average annual rainfall of about $318 \mathrm{~cm}$ with maximum rainfall occurring during the months of May to November. The relative humidity varies from $79 \%$ to $89 \%$ and the mean maximum and minimum temperature fluctuate between 27 to $33^{\circ} \mathrm{C}$ and 21 to $25^{\circ} \mathrm{C}$ respectively. The major land forms are longitudinal hills, hill slopes, mid hill valley and coastal plains. Plantations of coconut and arecanut grown in the hill slopes occupy about $48.1 \%$ of total cropped area while seasonal crops like rice, pulses, maize and vegetables are mainly grown in mid hill valley and coastal plains. The soils are predominantly sandy clay to sandy clay loam in texture, acidic, medium to high in organic matter and poor in available phosphorus (P) and potassium $(\mathrm{K})$ content.

\subsection{Organic Waste Materials}

Four different sources of organic wastes were used in this study viz. crop residues, coconut husk, garden wastes and gliricidia. Poultry manure and cattle manure were used as starters and to narrow down $\mathrm{C} / \mathrm{N}$ ratio of the organic wastes during composting. The earthworms (Eisenia foetida) were introduced into the tanks 1 month after filling the materials during which the released heat facilitated in precomposting the fibrous coconut husk. The coconut husk vermicompost was ready by 150 to 160 days while vermicompost prepared from crop residues such as rice straw, gliricidia, cattle manure and the compost was ready within 120 days. These materials were dried and used for application.

\subsection{Characterization of Organics}

Random samples were taken from the organic wastes used in the field experiment and processed for chemical determination. The $\mathrm{pH}$ of organic amendments was measured in a suspension of $1.5 \mathrm{~g}$ sample in $30 \mathrm{~mL}$ of 0.002 $\mathrm{M} \mathrm{CaCl}_{2}$ (Wong et al., 1998). Total $\mathrm{N}$ content of the organics were extracted in di acid containing perchloric $\left(\mathrm{HClO}_{4}\right)$ and sulfuric $\left(\mathrm{H}_{2} \mathrm{SO}_{4}\right)$ acid mixture and estimated in Kelplus Nitrogen estimation system. Total P, K, Ca, $\mathrm{Mg}$ and $\mathrm{Na}$ were extracted in wet digestion with triple acid using perchloric acid $\left(\mathrm{HClO}_{4}\right)$, sulfuric acid $\left(\mathrm{H}_{2} \mathrm{SO}_{4}\right)$, and nitric acid $\left(\mathrm{HNO}_{3}\right)$. The $\mathrm{Ca}$ and $\mathrm{Mg}$ were estimated using atomic absorption spectrometry, whereas $\mathrm{Na}$ and $\mathrm{K}$ in flame photometry. The total $\mathrm{P}$ was estimated by wet digestion followed by phosphomolibdate complex formation and determination in UV-Vis spectrophotometer.

\subsection{Experimental Site}

A field experiment was carried out in an Inceptisol located in Horticultural Research Farm of Central Agricultural Research Institute, Port Blair. The soil of experimental site was sandy loam (sand: $74.0 \%$, silt: $8.0 \%$ \& clay: $18.0 \%)$, strongly acidic $\left(\mathrm{pH}_{\mathrm{CaCl} 2} 4.19\right)$, non saline $\left(\mathrm{ECW} 0.36 \mathrm{dSm}^{-1}\right)$. The soil organic carbon was $0.35 \mathrm{~g}$ $\mathrm{kg}^{-1}$ available $\mathrm{N}$ and $\mathrm{P}$ contents were 124.3 and $5.6 \mathrm{mg} \mathrm{kg}^{-1}$ respectively. The cation exchange capacity was 8.51 $\mathrm{cmol}_{\mathrm{c}} \mathrm{kg}^{-1}$ soil with exchangeable Ca $3.01 \mathrm{cmol}_{\mathrm{c}} \mathrm{kg}^{-1}$ soil. The exchange acidity was $2.65 \mathrm{cmol}_{\mathrm{c}} \mathrm{kg}^{-1}$ soil with $0.84 \mathrm{cmol}_{\mathrm{c}} \mathrm{kg}^{-1}$ soil of exchangeable $\mathrm{Al}^{3+}$.

\subsection{Experimental Description}

The experiment was conducted during dry season (November to April) of 2011 and 2012 in a Randomized Block Design (RBD) of $3 \mathrm{~m} \times 3 \mathrm{~m}$ size plots with 7 treatments viz., control (T1), poultry manure (T2), vermicompost (T3), gliricidia (T4), coconut husk compost (T5), coconut husk compost + lime (T6) and lime (T7) with three replications. The organics were applied at the rate of $20 \mathrm{tha}^{-1}, 10$ days before sowing of the maize crop and incorporated well in to the soil. The lime $\left(4 \mathrm{t} \mathrm{ha}^{-1}\right)$ was applied based on lime requirement of the soil to bring the pH to 7.0 (Shoemaker et al., 1961). Two maize seeds (Zea mays, variety NK6240) were dibbled at a spacing of 
$60 \times 25 \mathrm{~cm}$ and later thinned to one per stand after two weeks of sowing. Though the crop was rainfed two irrigations were given during critical growth stages. Standard package of practices were followed for other intercultural operations.

\subsection{Soil and Plant Analyses}

Surface soil samples $(0-15 \mathrm{~cm})$ were taken before the experiment and at 1, 45 and 120 days after application of amendments in both the years. Each sample was a composite of 6 sub-samples collected from each plot. The air dried soil was ground to pass through $2 \mathrm{~mm}$ sieve prior to analysis. The soil $\mathrm{pH}$ was measured in $2 \mathrm{mM} \mathrm{CaCl}_{2}$ in a soil to solution ratio of 1:2. The cation exchange capacity and exchangeable cations were done by extracting with $\mathrm{N}, \mathrm{N}$ Ammonium acetate $\left(\mathrm{NH}_{4} \mathrm{OAC}\right)$ (Chapman, 1965). After extraction, the determination of exchangeable cations was done by atomic absorption spectrometer ( $\mathrm{Ca}$ and $\mathrm{Mg}$ ) and flame photometer ( $\mathrm{Na}$ and $\mathrm{K}$ ). Exchange acidity and exchangeable aluminum were done by extracting with $1 \mathrm{~N} \mathrm{KCl} \mathrm{(McLean,} \mathrm{1965).} \mathrm{Total} \mathrm{N}$ content of soil was determined by Kjeldahl method. The relative liming efficiency was calculated for each organic material used alone or in combination as per the method given by Gichangi and Mnkeni (2009).

\subsection{Maize Growth and Yield Parameters}

Growth parameters such as plant height $(\mathrm{cm})$, root length $(\mathrm{cm})$ and root volume $\left(\mathrm{cm}^{3}\right)$ were recorded for plant samples collected from each plot at the time of harvest. The yield parameters such as cob length $(\mathrm{cm}), 100$ grain weight $(\mathrm{g})$, grain yield $\left(\mathrm{t} \mathrm{ha}^{-1}\right)$, straw yield $\left(\mathrm{t} \mathrm{ha}^{-1}\right)$ and total biomass yield $\left(\mathrm{t} \mathrm{ha}^{-1}\right)$ were recorded for each plot in triplicates from each plot for both the years. The root length was measured by the line-intercept method (Tennant 1975) and root volume by volume displacement method.

\subsection{Statistical Analyses}

The data recorded were subjected to analysis of variance (ANOVA) for a randomized block design with three replications using the SAS software package. The comparison of means was performed by Fisher's Least Significant difference (LSD) at $95 \%$ level of probability and correlation analysis was done to determine relationship between the parameters.

\section{Results and Discussion}

\subsection{Properties of Organic Amendments}

The analyses of physico-chemical properties of different organics (Table 1) indicated a significant differences in $\mathrm{pH}$, total nutrients, base cation content and proton consumption capacity $(\mathrm{p}<0.05)$. Among the organics gliricidia had the lowest $\mathrm{pH}$ (5.1) while poultry manure recorded highest value of 8.9. Similarly, poultry manure recorded significantly higher amounts of total $\mathrm{N}$, $\mathrm{P}$ besides base cations like $\mathrm{K}, \mathrm{Ca}$ and $\mathrm{Mg}$ as compared to others. The proton consumption capacity (PCC) and $\mathrm{CaCO}_{3}$ equivalent of the materials were in the order of poultry manure $>$ vermicompost $>$ coconut husk compost $>$ gliricidia, which could be attributable to differences in their total base content (Wong et al., 1998). This was evidenced from linear relationship between $\mathrm{pH}$ and total base cations content of the materials expressed in $\mathrm{cmolkg}^{-1}\left(\mathrm{r}^{2}=0.92\right)$ as well as proton consumption capacity and total base cations $\left(r^{2}=0.89\right)$. The highest $\mathrm{CaCO}_{3}$ equivalent recorded for poultry manure was directly related to its total $\mathrm{Ca}$ and $\mathrm{Mg}$ content. The results indicated a wide scope for improving the properties of organic materials to desirable level by mixing different materials either before or after composting.

Table 1. Selected properties of organic manures/composts used in the study

\begin{tabular}{cccccc}
\hline \multirow{2}{*}{ Parameter } & \multirow{2}{*}{ Unit } & \multicolumn{4}{c}{ Concentration (mean of three replicates)* } \\
\cline { 3 - 6 } & & $\mathrm{PM}$ & $\mathrm{VC}$ & $\mathrm{GL}$ & $\mathrm{CHC}$ \\
\hline $\mathrm{pH}(2 \mathrm{mM} \mathrm{CaCl2})$ & - & 8.9 & 7.6 & 5.1 & 6.5 \\
Total N & $\mathrm{g} \mathrm{kg}^{-1}$ & 27.1 & 17.3 & 22.6 & 8.7 \\
Total $\mathrm{P}$ & $\mathrm{g} \mathrm{kg}^{-1}$ & 14.3 & 9.1 & 1.7 & 1.2 \\
Total $\mathrm{K}$ & $\mathrm{g} \mathrm{kg}^{-1}$ & 18.2 & 5.8 & 11.9 & 14.2 \\
Total Ca & $\mathrm{g} \mathrm{kg}^{-1}$ & 24.9 & 13.1 & 12.7 & 14.3 \\
Total Mg & $\mathrm{g} \mathrm{kg}^{-1}$ & 10.1 & 6.6 & 3.7 & 6.3 \\
$\mathrm{H}^{+}$consumption capacity & $\mathrm{cmol} \mathrm{kg}^{-1}$ & 646.7 & 343.1 & 46.2 & 162.6 \\
CaCO $_{3}$ equivalent & $\mathrm{g} \mathrm{kg}^{-1}$ & 100.8 & 57.3 & 14.6 & 46.1 \\
\hline
\end{tabular}

* PM - poultry manure; VC - Vermicompost; GL - Gliricidia; CH - Coconut husk compost. 


\subsection{Effects on Soil pH and Acidity}

The application of organic amendments had significant impact on the soil $\mathrm{pH}$ but the effect was less than that of lime addition. Among the organics, poultry manure $(\mathrm{T} 2)$ showed significant increase $(\mathrm{p}<0.05)$ in soil $\mathrm{pH}$ on application. The increase in soil $\mathrm{pH}$ immediately upon addition of organic materials is due to proton $\left(\mathrm{H}^{+}\right)$ exchange between the soil and added organic material (Wong et al., 1998). This was mainly governed by initial soil $\mathrm{pH}$, proton consumption capacity and $\mathrm{pH}$ of organic materials used (Marschner \& Noble, 2000). This was evidenced from the order of increase in soil $\mathrm{pH}$ viz. poultry manure $>$ vermicompost $>$ coconut husk compost $>$ gliricidia.

Temporal observations of soil $\mathrm{pH}$ over crop growth period indicated that it attained a peak values at around 45 days after application and decreased at the time of harvest of the crop in all the organic treatments except coconut husk compost (T5) amended soils (Table 2). This increase was attributable to ammonification of organic nitrogen and microbial decarboxylation due to proton consumption (Yan et al., 1996). The general decrease in soil $\mathrm{pH}$ observed after 45 days of application was attributable to nitrification of manure derived $\mathrm{N}$ (Hoyt \& Turner, 1975). The continuous increase in $\mathrm{pH}$ in coconut husk compost and lime applied either alone or in combination (T5, T6 and T7) might be due to progressive dissolution of lime and slow decomposition of coconut husk compost due to to higher $\mathrm{C}: \mathrm{N}$ ratio as compared to other organics used in this study. Similar trend was observed during second year of application as well. The soil $\mathrm{pH}$ taken before application of amendments in the second year of cultivation showed significant reduction (10-12\%) where lime was applied (T6 and T7) than addition of organics alone (Figure 1). This decrease might be due to leaching of soluble cations like $\mathrm{Ca}^{2+}$ due to heavy intensive rainfall of more than $2.5 \mathrm{~m}$ received during rainy season (May to November) after harvest of the crop. The degree of reduction was least in coconut husk compost (3\%) applied soil as compared to other organics which is attributable to its slow decomposition due to higher $\mathrm{C}: \mathrm{N}$ ratio.

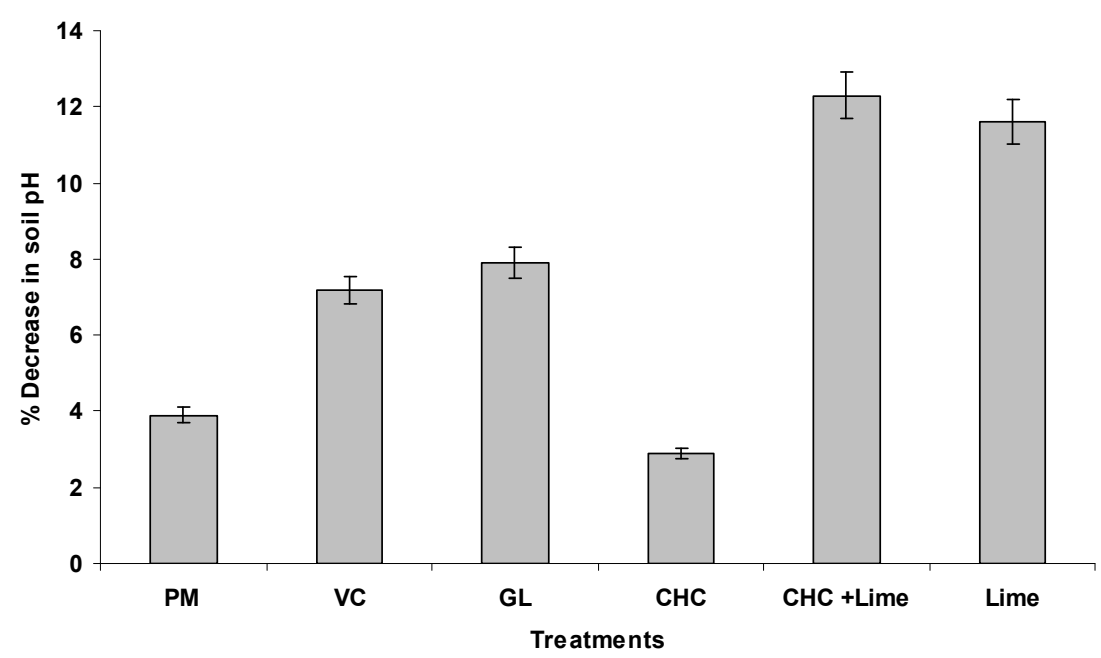

Figure 1. Percent decrease in soil $\mathrm{pH}$ one year after treatments 
Table 2. Temporal changes in soil $\mathrm{pH}$ and relative liming efficiency as affected by organics and lime

\begin{tabular}{|c|c|c|c|c|c|c|}
\hline \multirow{3}{*}{ Treatment } & \multicolumn{6}{|c|}{$\begin{array}{c}\text { Soil } \mathrm{pH}(2 \mathrm{mM} \mathrm{CaCl}) \\
\text { Days after application of amendments }\end{array}$} \\
\hline & \multicolumn{3}{|c|}{2010} & \multicolumn{3}{|c|}{2011} \\
\hline & $\mathbf{0}$ & 45 & 120 & $\mathbf{0}$ & 45 & 120 \\
\hline Control & $4.22^{\mathrm{c}}$ & $4.16^{\mathrm{e}}$ & $4.21^{\mathrm{d}}$ & $4.17^{\mathrm{d}}$ & $4.22^{\mathrm{d}}$ & $4.26^{\mathrm{d}}$ \\
\hline Poultry Manure (PM) & $4.97^{\mathrm{b}}$ & $5.65^{\mathrm{c}}$ & $4.64^{\mathrm{c}}$ & $5.11^{\mathrm{c}}$ & $5.70^{\mathrm{b}}$ & $5.31^{\mathrm{b}}$ \\
\hline Vermicompost (VC) & $4.74^{\mathrm{bc}}$ & $4.88^{\mathrm{d}}$ & $4.67^{\mathrm{c}}$ & $4.70^{\mathrm{cd}}$ & $4.93^{\mathrm{c}}$ & $4.65^{\mathrm{cd}}$ \\
\hline Gliricidia (GL) & $4.32^{\mathrm{c}}$ & $4.48^{\mathrm{d}}$ & $4.73^{\mathrm{c}}$ & $4.65^{\mathrm{cd}}$ & $4.74^{\mathrm{cd}}$ & $4.48^{\mathrm{d}}$ \\
\hline Coconut Husk Compost (CHC) & $4.43^{\mathrm{c}}$ & $4.64^{\mathrm{d}}$ & $4.86^{\mathrm{c}}$ & $4.81^{\mathrm{c}}$ & $5.12^{\mathrm{bc}}$ & $5.26^{\mathrm{bc}}$ \\
\hline Coconut Husk Compost + Lime & $6.69^{\mathrm{a}}$ & $6.46^{\mathrm{b}}$ & $6.52^{\mathrm{b}}$ & $6.04^{\mathrm{b}}$ & $6.45^{\mathrm{a}}$ & $6.43^{\mathrm{a}}$ \\
\hline Lime & $6.82^{\mathrm{a}}$ & $7.14^{\mathrm{a}}$ & $7.06^{\mathrm{a}}$ & $7.12^{\mathrm{a}}$ & $6.98^{\mathrm{a}}$ & $6.94^{\mathrm{a}}$ \\
\hline $\operatorname{LSD}_{(0.05)}$ & 0.40 & 0.25 & 0.26 & 0.61 & 0.58 & 0.62 \\
\hline
\end{tabular}

Figureures having different superscript letters in each column indicate statistical significance at $\mathrm{p}<0.05$.

The application of amendments resulted in decrease in exchangeable acidity and exchangeable $\mathrm{Al}^{3+}$ (Figure 2). Neither exchangeable acidity nor exchangeable $\mathrm{Al}^{3+}$ was observed in lime (T7) treated soils, while significant reductions were found in other treatments viz., poultry manure, vermicompost, coconut husk compost + lime. This is attributable to precipitation of soluble and exchangeable $\mathrm{Al}^{3+}$ into hydroxy- $\mathrm{Al}$ species at $\mathrm{pH}$ above 5.5, thus reducing $\mathrm{Al}$ toxicity to crop growth (Haynes \& Mokolobate, 2001). This reduction in exchangeable $\mathrm{Al}^{3+}$ is important for crop growth as it is most toxic to plant roots (Vieira et al., 2008). Escobar Ortiz and Hue (2008) also showed a similar decrease in exchangeable $\mathrm{Al}^{3+}$ by application of organic amendments in tropical acid soils of Hawaii.

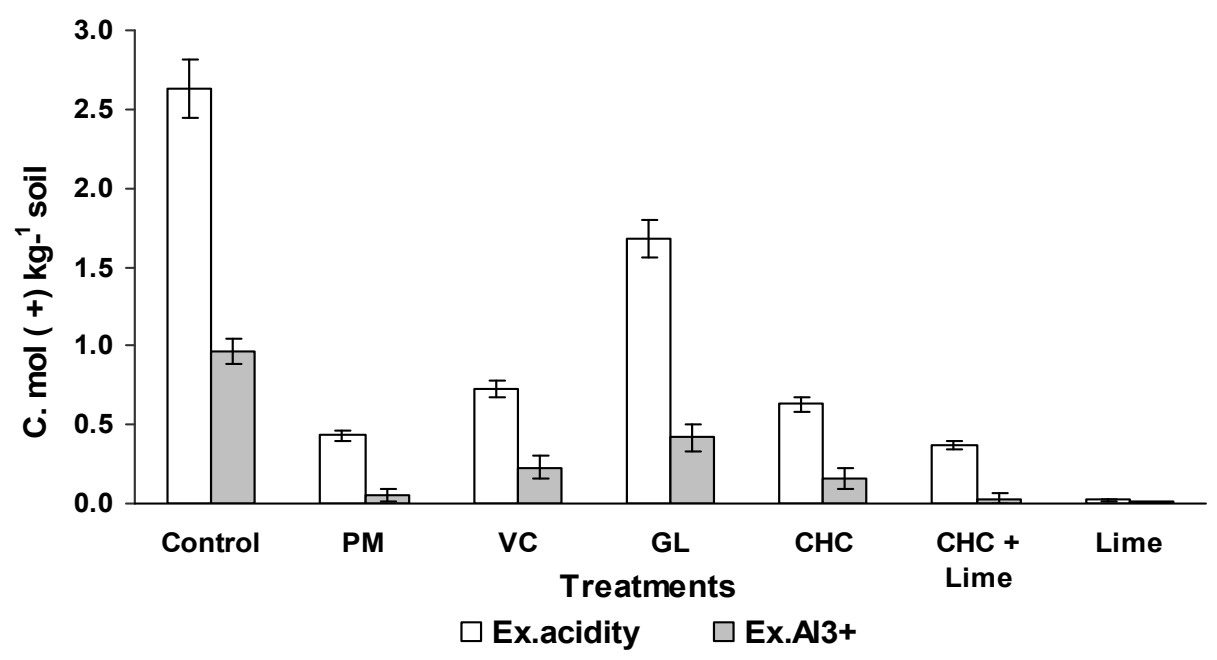

Figure 2. Effects of various amendments on soil exchange acidity and Ex.Al ${ }^{3+}$

Several authors (Escobar Ortiz \& Hue 2008; The et al., 2006; Ghosh et al., 2010) reported the superiority of poultry manure in increasing plant available nutrients as a result of improvement in soil acidity. The differences in availability of plant available nutrients among various treatments could be attributable to differences in chemical composition of the organics used (Nziguheba et al., 1998) and rate of application (Reddy et al., 1980).

\subsection{Relative Liming Efficiency}

The relative liming efficiency (RLE) is a dynamic relation which changes over a period of observation 
depending on the changes in soil pH by application of amendments. In general RLE was significantly higher for poultry manure (T2) as compared to other organics used (Figure 3), which is attributable to higher $\mathrm{CaCO}_{3}$ equivalent of the poultry manure resulting from its higher $\mathrm{Ca}^{2+}$ and $\mathrm{Mg}^{2+}$ content. However highest RLE was observed in coconut husk + lime (T6) amended soils mainly because of lime addition. At the end of the experiment the RLE of coconut husk compost (T5) was on par with that of poultry manure. Gichangi \& Mnkeni (2009) also reported similar liming effect by application of goat manure for a period of 84 days in soils of Transkei region, South Africa.

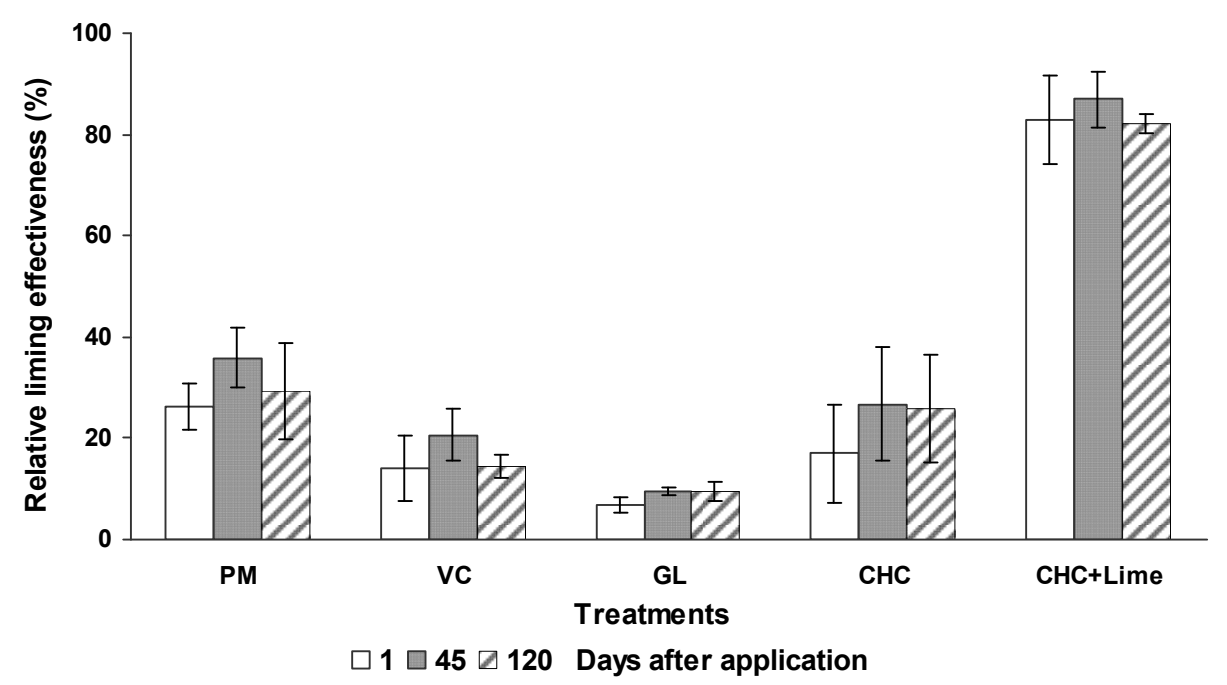

Figure 3. Relative liming effectiveness of organic amendments applied to acid soils under field condition

\subsection{Maize Growth and Yield}

Organic manures are used for crop production to improve yield from time immemorial. This study also demonstrated that growth and yield parameters of maize crop were significantly $(p<0.05)$ affected by application of soil amendments as compared to control (Table 3). The plant height increased from $135.3 \mathrm{~cm}$ in control to $210.0 \mathrm{~cm}$ in poultry manure amended soils. The organics such as poultry manure, vermicompost, gliricidia and coconut husk application recorded on par results followed by lime and coconut husk + lime application. Similar trend was also observed for other parameters like cob length, grain weight per cob and 100 grain weight. The cob length showed significant differences between poultry manure, vermicompost, gliricidia and coconut husk, coconut husk + lime and lime alone. This was directly reflected in related parameters viz., grain weight per cob and 100 grain weight. The maize grain yield for two year average indicated that the application of organic amendments significantly increased the yield as compared to control. The poultry manure and vermicompost application recorded on par yield followed by gliricidia $\left(3.47 \mathrm{t} \mathrm{ha}^{-1}\right)$ and coconut husk + lime $\left(3.03 \mathrm{t} \mathrm{ha}^{-1}\right)$. Similar increase in maize yield by organics especially by poultry manure and vermicompost was also reported by Amusan et al. (2011). Similarly poultry manure amended plots recorded significantly higher stover yield $\left(12.67 \mathrm{t} \mathrm{ha}^{-1}\right)$ with total biological yield of $16.46 \mathrm{tha}^{-1}$ followed by vermicompost $\left(11.05,14.78 \mathrm{tha}^{-1}\right)$ and gliricidia $\left(10.85,14.32 \mathrm{t} \mathrm{ha}^{-1}\right)$ application mainly by improved $\mathrm{N}$ availability. Though the soil $\mathrm{pH}$ improved by application of lime, the addition of organic manures significantly improved the growth and yield parameters because of additional nutrient supply especially nitrogen and phosphorus besides improved microbial activity. 
Table 3. Maize growth and yield parameters as affected by soil amendments (Mean of 2 years)

\begin{tabular}{|c|c|c|c|c|c|c|c|}
\hline Treatment & $\begin{array}{l}\text { Plant Height } \\
\text { (cm) }\end{array}$ & $\begin{array}{l}\text { Cob length } \\
\qquad \text { (cm) }\end{array}$ & $\begin{array}{l}\text { Grain wt } \\
\operatorname{cob}^{-1}(g)\end{array}$ & 100 grain wt $\quad(g)$ & $\begin{array}{c}\text { Grain yield } \\
\qquad\left(\mathrm{t} \mathrm{ha}^{-1}\right)\end{array}$ & $\begin{array}{l}\text { Stover yield } \\
\qquad\left(\mathrm{t} \mathrm{ha}^{-1}\right)\end{array}$ & $\begin{array}{l}\text { Biological yield } \\
\qquad\left(\mathrm{t} \mathrm{ha}^{-1}\right)\end{array}$ \\
\hline Control & $135.3^{\mathrm{c}}$ & $11.9^{\mathrm{c}}$ & $50.2^{\mathrm{d}}$ & $10.34^{\mathrm{b}}$ & $1.93^{\mathrm{e}}$ & $6.10^{\mathrm{e}}$ & $8.03^{\mathrm{e}}$ \\
\hline Poultry Manure & $210.0^{\mathrm{a}}$ & $21.1^{\mathrm{a}}$ & $96.7^{\mathrm{a}}$ & $19.04^{\mathrm{a}}$ & $3.79^{\mathrm{a}}$ & $12.67^{\mathrm{a}}$ & $16.46^{\mathrm{a}}$ \\
\hline Vermicompost & $207.7^{\mathrm{a}}$ & $19.9^{\mathrm{a}}$ & $95.4^{\mathrm{a}}$ & $18.02^{\mathrm{a}}$ & $3.73^{\mathrm{a}}$ & $11.05^{\mathrm{b}}$ & $14.78^{\mathrm{b}}$ \\
\hline Gliricidia & $212.3^{\mathrm{a}}$ & $19.4^{\mathrm{a}}$ & $88.1^{\mathrm{a}}$ & $17.69^{\mathrm{a}}$ & $3.47^{\mathrm{b}}$ & $10.85^{\mathrm{b}}$ & $14.32^{\mathrm{b}}$ \\
\hline CH Compost & $199.0^{\mathrm{a}}$ & $15.3^{\mathrm{bc}}$ & $72.8^{\mathrm{bc}}$ & $12.23^{\mathrm{b}}$ & $2.27^{\mathrm{d}}$ & $7.26^{\mathrm{d}}$ & $9.53^{\mathrm{d}}$ \\
\hline CH Compost + Lime & $192.0^{\mathrm{ab}}$ & $17.2^{\mathrm{bc}}$ & $85.1^{\mathrm{ab}}$ & $13.48^{\mathrm{b}}$ & $3.03^{\mathrm{c}}$ & $8.30^{\mathrm{c}}$ & $11.33^{\mathrm{c}}$ \\
\hline Lime & $168.3^{\mathrm{b}}$ & $16.4^{\mathrm{b}}$ & $63.8^{\mathrm{cd}}$ & $14.81^{\mathrm{b}}$ & $2.55^{\mathrm{d}}$ & $7.66^{\mathrm{d}}$ & $10.21^{\mathrm{d}}$ \\
\hline $\operatorname{LSD}_{(0.05)}$ & 26.4 & 3.5 & 14.9 & 5.54 & 0.28 & 0.50 & 0.70 \\
\hline
\end{tabular}

Figureures having different superscript letters in each column indicate statistical significance at $\mathrm{p}<0.05$.

The effect of soil amendments on root parameters like root length and root volume was presented in Figure 4 . Although no significant difference was found in root length by application of soil amendments especially organics, significant differences were observed in root volume by application of $\mathrm{N}$ rich organic sources like poultry manure $\left(50.0 \mathrm{~mm}^{3}\right)$, vermicompost $\left(46.7 \mathrm{~mm}^{3}\right)$ and gliricidia $\left(40.0 \mathrm{~mm}^{3}\right)$ as compared to control $(11.7$ $\mathrm{mm}^{3}$ ) and lime $\left(23.3 \mathrm{~mm}^{3}\right)$ applications. The improved root volume might have helped in increasing volume of soil foraged by the roots thereby increasing nutrient availability, which in turn resulted in increased growth and yield of maize.

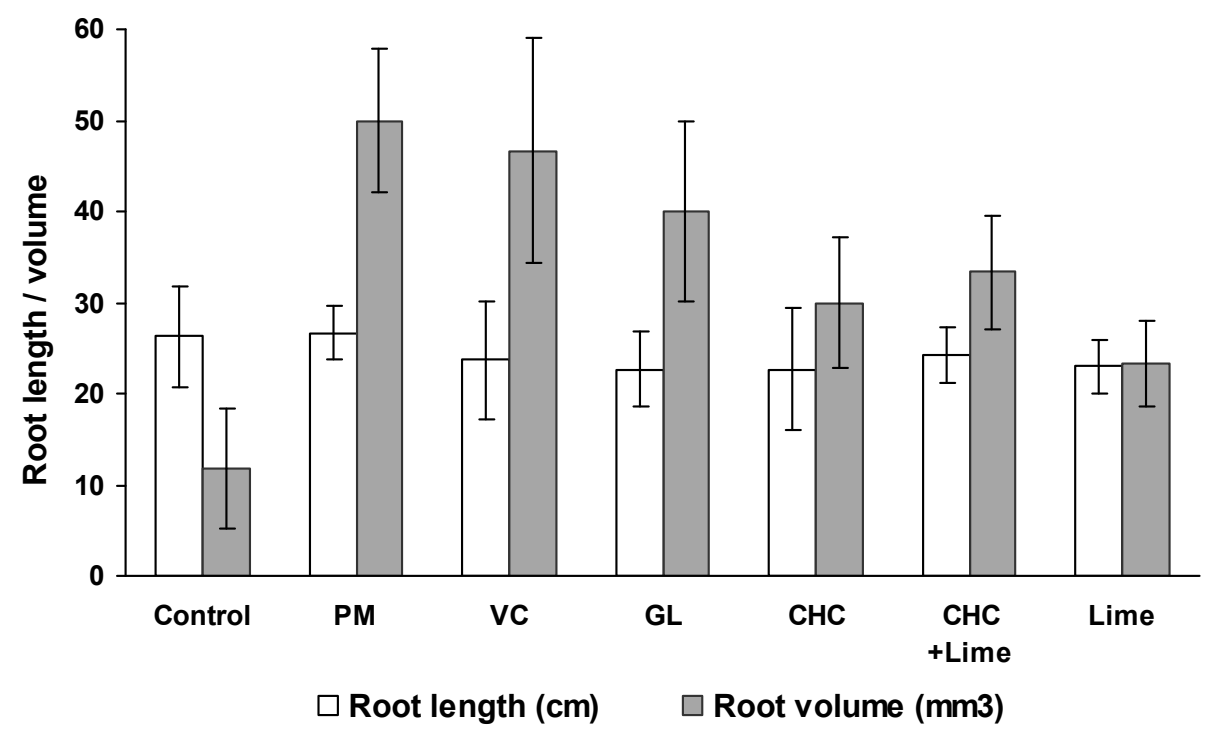

Figure 4. Amendment effect of organics on root length and root volume of maize

\section{Conclusions}

In tropical island conditions every available resource is very precious and different organic wastes produced locally can be effectively recycled through composting methods. The study showed the amendment effect of different organic materials by improving soil $\mathrm{pH}$ and reducing aluminum which is toxic to crop plants. The maize growth and yield was also significantly improved by application of organic amendments especially poultry manure, vermicompost and gliricidia. The coconut husk compost has the potential to be a soil 
amendment if the proportion of poultry manure added is increased to improve its nutrient content. Otherwise it can be mixed with poultry manure during application to the crops. Such an approach is very beneficial effective recycling of wastes available on farm and for improving crop production.

\section{Acknowledgements}

The authors are grateful to Central Agricultural Research Institute, Port Blair for financial assistance provided for successful completion of this study. The authors are thankful to Director of this institute for his guidance and support at various levels. The help and support received from technical, research and supporting staff of Division of Natural Resource Management and Project Monitoring Cell are thankfully acknowledged.

\section{References}

Amusan, A. O., Adetunji, M. T., Azeez, J. O., \& Bodunde, J. G. (2011). Effect of the integrated use of legume residue, poultry manure and inorganic fertilizers on maize yield, nutrient uptake and soil properties. Nutrient Cycling in Agroecosystems, 90, 321-330. http://dx.doi.org/10.1007/s10705-011-9432-6

Chandrashekara, S. I., Harlapur, S., Muralikrishan, \& Girijesh, G. K. (2000). Response of maize to organic manures with inorganic fertilizers. Karnataka Journal of Agricultural Sciences, 13, 144-146.

Chapman, H. D. (1965). Cation-exchange capacity. In C. A. Black (ed.), Methods of soil analysis - Chemical and microbiological properties. Agronomy, 9, 891-901.

Din, M., Ravisankar, N., \& Ambast, S. K. (2008). Suitable wastes for vermicomposting. Training manual on vermicomposting (pp. 14-17). Director, CARI, Port Blair.

Escobar Ortiz, M. E., \& Hue, N. V. (2008). Temporal changes of selected chemical properties in three manureamended soils of Hawaii. Bioresource Technology, 99, 8649-8654. http://dx.doi.org/10.1016/j.biortech.2008.04.069

Ghosh, S., Lockwood, P., Daniel, H., King, K., Hulugalle, N., \& Kristiansen, P. (2010). Short-term effects of organic amendments on properties of a Vertisol. Waste Management \& Research, 28, 1087-1095. http://dx.doi.org/10.1177/0734242X09359105

Gichangi, E. M., \& Mnkeni, P. N. S. (2009). Effect of goat manure and lime addition on phosphate sorption by two soils from the Transkei region, South Africa. Communications of Soil Science \& Plant Analysis, 40, 3335-3347. http://dx.doi.org/10.1080/00103620903325943

Haynes, R. J., \& Mokolobate, M. S. (2001). Amelioration of Al toxicity and P deficiency in acid soils by additions of organic residues: a critical review of the phenomenon and the mechanisms involved. Nutrient cycling in Agroecosystems, 59, 47-63. http://dx.doi.org/10.1023/A:1009823600950

Hoyt, P. B., \& Turner, R. C. (1975). Effects of organic materials added to a very acid soil on pH, aluminium, $\begin{array}{lllllll}\text { exchangeable } & \mathrm{NH}_{4} & \text { and } & \text { crop } & \text { yield. } & \text { Soil } & \text { Science, }\end{array}$ http://dx.doi.org/10.1097/00010694-197503000-00008

Kochian L. V., Hoekenga, O., \& Mapineros. (2004). Plant mechanisms of acid soil tolerance. Annual Review of Plant Biology, 55, 459-493. http://dx.doi.org/10.1146/annurev.arplant.55.031903.141655

Marschner, B., \& Noble, A. D. (2000). Chemical and biological processes leading to the neutralization of acidity in soil incubated with litter materials. Soil Biology \& Biochemistry, 32, 805-813. http://dx.doi.org/10.1016/S0038-0717(99)00209-6

Materechera, S. A. (2012). Using wood ash to ameliorate acidity and improve phosphorus availability in soils amended with partially decomposed cattle or chicken manure. Communications in Soil Science \& Plant Analysis, 43, 1773-1789. http://dx.doi.org/10.1080/00103624.2012.684825

McLean, E. O. (1965). Aluminium. In C. A. Black (Ed.), Methods of Soil Analysis, Part 2: Chemical and Biological Properties (pp. 987-990). American Society of Agronomy, Madison, WI, USA.

Nziguheba, G., Merckx, R., Palm, C. A., \& Rao, R. M. (2000). Organic residues affect phosphorus availability and maize yields in a Nitisol of western Kenya. Biology \& Fertility of Soils, 32, 328-339. http://dx.doi.org/10.1007/s003740000256

Nziguheba, G., Palm, C. A., Buresh, R. J., \& Smithson, P. C. (1998). Soil phosphorus fractions and adsorption as affected by organic and inorganic sources. Plant \& Soil, 198, 159-168. http://dx.doi.org/10.1023/A:1004389704235 
O’Hallorans, J., Munoz, M. A., \& Marquez, P. E. (1997). Chicken manure as an amendment to correct soil acidity and fertility. Journal of Agriculture of the University of Porto Rico, 81, 1-8.

Reddy, K. R., Overcash, M. R., Khaleel, R., \& Westerman, P. W. (1980). Phosphorus adsorption-desorption characteristics of two soils utilized for disposal of animal wastes. Journal of Environmental Quality, 9, 86-92. http://dx.doi.org/10.2134/jeq1980.9186

Sanchez, P., Shepard, K., Soule, M., Place, F., \& Buresh, R. (1997). Soil fertility replenishment in Africa. An investment in natural resource capital. In R. Buresh, P. Sanchez, \& F. Calhoun (Eds.), Replenishing Soil Fertility in Africa. (pp. 1-46), Soil Science Society of America Special Publication, No. 51, Madison, Wisconsin, USA.

Shoemaker, H. E., McLean, E. O., \& Pratt, P. F. (1961). Buffer methods for determining lime requirement of soils with appreciable amounts of extractable aluminum. Soil Science Society of America Proceedings, 25, 274-277. http://dx.doi.org/10.2136/sssaj1961.03615995002500040014x

Tennant, D. (1975). A test of a modified line intersect method of estimating root length. Journal of Ecology, 63, 995-1001. http://dx.doi.org/10.2307/2258617

The, C., Calba, H., Zonkeng, C., Ngonkeu, M., Adetimirin, V. O., Mafousson, H. A., ... Horst, W. J. (2006). Responses of maize grain yield to changes in acid soil characteristics after soil amendments. Plant \& Soil, 284, 45-57. http://dx.doi.org/10.1007/s11104-006-0029-9

Vieira, C. B. F., He, Z. L., Bayer, C., Stoffella, P. J., \& Baligar, V. C. (2008). Organic amendment effects on the transformation and fractionation of aluminum in acidic sandy soil. Communications in Soil Science \& Plant Analysis, 39, 2678-2694. http://dx.doi.org/10.1080/00103620802358813

Wong, M. T. F., \& Swift, R. S. (2003). Role of organic matter in alleviating soil acidity. In R. Zdenko (Ed.), Handbook of soil acidity (pp. 337-358). Marcell Dekker, New York, USA. http://dx.doi.org/10.1201/9780203912317.ch12

Wong, M. T. F., Nortcliff, S., \& Swift, R. S. (1998). Method for determining the acid ameliorating capacity of plant residues compost, urban waste compost, farm yard manure and peat applied to tropical soils. Communications in Soil Science \& Plant Analysis, 19\&20, 2927-2937. http://dx.doi.org/10.1080/00103629809370166

Yan, F., Schubert, S., \& Mengel, K. (1996). Soil pH increase due to biological decarboxylation of organic anions. Soil Biology \& Biochemistry, 28, 617-624. http://dx.doi.org/10.1016/0038-0717(95)00180-8

\section{Copyrights}

Copyright for this article is retained by the author(s), with first publication rights granted to the journal.

This is an open-access article distributed under the terms and conditions of the Creative Commons Attribution license (http://creativecommons.org/licenses/by/3.0/). 